\title{
Mechanical Behavior of the Reinforced Retaining Wall Subjected to Static Load
}

\author{
Yong Liu $\left(\mathbb{D},{ }^{1,2}\right.$ Zhanyong Yao, ${ }^{1}$ Hongzhe Liu, ${ }^{2}$ Mingxia Shao, ${ }^{3}$ and Yulong Zhao ${ }^{2}$ \\ ${ }^{1}$ School of Civil Engineering, Shandong University, Jinan 250061, China \\ ${ }^{2}$ School of Civil Engineering, Shandong Jiaotong University, Jinan 250357, China \\ ${ }^{3}$ School of Foreign Languages, Shandong Jianzhu University, Shandong, Jinan 250101, China
}

Correspondence should be addressed to Yong Liu; 204042@sdjtu.edu.cn

Received 6 March 2020; Revised 21 November 2020; Accepted 27 January 2021; Published 9 February 2021

Academic Editor: Melina Bosco

Copyright () 2021 Yong Liu et al. This is an open access article distributed under the Creative Commons Attribution License, which permits unrestricted use, distribution, and reproduction in any medium, provided the original work is properly cited.

To study the mechanical behavior and influence factors of the reinforced retaining wall under the static load, numerical simulation of the reinforced retaining wall is conducted by finite element analysis, and its mechanical behavior and influencing methods are studied in accordance with relevant theories. The results showed that the properties of back fill, reinforced spacing, reinforced stiffness, reinforced length, and panel stiffness all affect the mechanical behavior of retaining walls. According to the example calculations of different wall heights, the distribution of panel horizontal displacement and maximum tensile stress are analyzed. The gravel with good gradation has better durability and can reduce the amount of reinforcing steel; with the decrease of the reinforcement spacing, the deformation of the wall panel will become smaller, and the reinforcement effect will be improved; the length of reinforcement is not the longer the better, and the deformation of wall panel can be minimized at the suitable length; the larger the elastic modulus of the wall panel, the smaller the deformation of the wall panel will be.

\section{Introduction}

The reinforced earth retaining wall is to add tie bars in the soil and to use the friction between the tie bars and the soil for the optimization of the deformation conditions and engineering characteristics of the soil, as an attempt to stabilize the soil [1-3]. Maehara et al. [4] proposed the application of an anchor method that contains the inner and outer walls by using numerical simulation. Zhou began to investigate the stress characteristics of the reinforced retaining wall in 1987; he calculated the lateral pressure of the wall in accordance with Coulomb active earth pressure theory $[5,6]$. For a reinforced earth retaining wall with the height of $31 \mathrm{~m}$ and four steps, the foundation stress of each wall was less than $100 \mathrm{kPa}$, and the earth pressure on the back of the wall displayed a curve distribution [7]. Li and Ehrlich conducted a study on the internal and reinforced material stresses of the block-type reinforced earth retaining wall under the load of the top of the wall, as well as the wall deformation, reinforced material strain, and other variations
$[8,9]$. Xiao and Abdelouhab carried out a comprehensive analysis on the effect of foundation location, load size, frequency, and cycle times on the mechanical and deformation performance of the reinforced retaining wall $[10,11]$. In the design of the reinforced earth retaining wall by the centrifuge model test performed by Ling, Yang, and $\mathrm{Li}$ [12-14], the effect of geotechnical effect should be fully considered to ensure the structural safety. Finally, Ahn et al. [15] used dyna-ls reinforcement program to analyze the mechanical performance of reinforced earth retaining wall under different reinforcement spacing and location.

The reinforced retaining wall structure is not only subjected to the earth pressure on the wall, the tension of the reinforcement belt, and the friction between the filler and the reinforcement belt but also affected by the side pressure exerted by the filling behind the end of the reinforcement belt and the possible load exerted on the outside of the free wall [16-18]. Given this, the numerical analysis model adopts the separate calculation model that considers the interaction between the geogrid and the soil [19-21]. 
Besides, Wang et al. [22] adopted deformation buffer zone and obtained the wall face horizontal displacement, vertical and horizontal soil pressures, and geogrid strains. As well as $\mathrm{Hu}$ et al. [23] used the horizontal differential layer element method to study the active earth pressure of the finite-width soil formed by the rigid retaining wall for the embankment or adjacent foundation pits.

Finn et al. [24] and Chen [25] used the limit analysis method to study the classical Coulomb straight line failure mechanism. The plastic limit analysis method was used to calculate the active and passive earth pressures under various failure mechanisms, which reduced the calculation error caused by the equivalent internal friction angle method. In the study of Jia et al. [26], based on the finite element geotechnical analysis technology platform, the deformation analysis model of reinforced soil retaining wall is established. The horizontal deformation rapidly increases after the spacing increases to $80 \mathrm{~cm}$. Handy [27] considered the soil arching effect and studied the distribution law of the earth pressure on the retaining wall using the strip method. The direction of the major principal stress near the retaining wall is deflected, and the horizontal lateral pressure is larger than that obtained by the traditional calculation method. Vermeer et al. [28] and Duncan [29] took rigid retaining wall as the research object and studied the earth pressure. It was found that the failure of the soil behind the wall followed the assumption of plane slip surface.

The objective of this research is to investigate the mechanical characteristics and influencing factors of reinforced retaining wall under static load for reducing the damage of reinforced retaining wall, such as lateral movement, overturn, settlement, or collapse completely. The finite element method was used to analyze the effects of factors on the stability of retaining wall.

\section{Establishment of Finite Element Analysis Model}

2.1. Project Profile. This paper is based on the reinforced soil retaining wall near K101 of Jihe expressway at both ends of the bridge from Pancun to Dayang. The length of the reinforced earth retaining wall is about 300 meters, and the maximum wall height is 14.5 meters. Table 1 lists the engineering geology of the finite element model. The reinforced earth retaining wall mainly has seven kinds of diseases, such as the wall bulge caused by excessive lateral deformation, the aging and spalling of fillers between expansion joints, the mortar falling off between the joints, the blockage of the water outlet at the top of the wall, the wall cracks, the rutting and cracks of the pavement on the top of the wall, and the cracking and collapse of the concrete guardrail on the top of the wall. Table 2 lists the design parameters of retaining wall.

2.2. Meshing and Selection of Model Parameters. Based on a project, the finite difference model is established, and the simulation data are obtained through calculation. By comparing and analyzing the simulated data with the measured data, the stress characteristics of the reinforced retaining wall under static load are obtained. The height of the retaining wall model is $14.5 \mathrm{~m}$, the depth of the reinforcement material is $5-8 \mathrm{~m}$, and the width of the subgrade model is $30 \mathrm{~m}$. The backfill part in the model adopts gravel soil. The size of panel in the model is $0.5 \mathrm{~m} \times 0.5 \mathrm{~m}$, the vertical spacing and horizontal spacing between the reinforcement belt nodes are $0.5 \mathrm{~m}$, and 30 layers of stripped steel-plastic composite tie belt are arranged in total. From top to bottom, there are 10 layers of $12 \mathrm{~m}$ long strip, 15 layers of $10 \mathrm{~m}$ long strip, 5 layers of $8 \mathrm{~m}$ long strip, and they are numbered 1-30 from bottom to top.

In the model, the soil element adopts the Mohr-Coulomb model, and linear elastic model is used for steel-plastic composite tie belt and panel. Under the action of static pressure, it involves the joint action of various structures such as retaining wall panels, wall backfill, and tensile reinforcement. Considering the complexity of its action mechanism, the retaining wall and back wall-filling use direct contact, while binding contact is used among the reinforcement, retaining wall, and back wall-filling. The retaining wall model and its finite element meshing are shown in Figure 1. The recommended design document is $35^{\circ}$ for the internal friction angle of the fill, and according to the tensile test result, the reinforcement material is $1356 \mathrm{kN} / \mathrm{m}$ in terms of the axial rigidity $E_{j}$. The deformation and internal stress state of the retaining wall under the design condition are calculated. Table 3 lists the material parameters of each structure of the retaining wall.

\section{Calculation and Analysis of Wall Panel Deformation}

3.1. Test Method. The finite difference model was established according to the actual engineering case, and the simulation data were obtained through calculation. The mechanical characteristics of reinforced retaining wall under static load were obtained by comparing the simulated data with the measured data.

In combination with the monitored results of deformation tracking of the retaining wall in the early stage and the relevant regulations with the limit strain of the reinforcement strip as $2 \%$ in the construction design documents, the output of the numerical simulation results places an emphasis on the horizontal displacement of the wall, as well as the strain of the reinforcement strip.

The numerical calculation of the reinforced retaining wall by the finite element method can obtain the calculation results of the lateral deformation of the wall panel, the stress strain and deformation of the fill, and the tensile force (tensile strain) of the reinforcement. For the actual reinforced retaining wall, the granular filling is generally selected, and after layered filling and compaction, the vertical deformation of the filling is generally very small. Therefore, the lateral deformation of the wall panel, the size and distribution of the tensile force of the reinforced layer, and the distribution form of the plastic area of the fill are largely analyzed in this study. 
TABLE 1: General situation of engineering geology.

\begin{tabular}{|c|c|}
\hline $\begin{array}{l}\text { Geographical } \\
\text { location }\end{array}$ & $\begin{array}{l}\text { It is located in the southwest of Shandong Province, the East Bank of the lower reaches of the Yellow River and the } \\
\text { West foot of Mount Tai }\end{array}$ \\
\hline $\begin{array}{l}\text { Geological } \\
\text { conditions }\end{array}$ & $\begin{array}{l}\text { It is a low mountain and hilly area with erosion and denudation structure. The ground surface fluctuates greatly, the } \\
\text { mountain body is relatively steep, the bedrock is exposed, the weathering and denudation are strong, and there is } \\
\text { abundant bedrock fissure karst water }\end{array}$ \\
\hline Climatic conditions & The average temperature over the years is $13.7^{\circ} \mathrm{C}$ \\
\hline Precipitation change & The average rainfall over the years is $644.4 \mathrm{~mm}$ \\
\hline Relative humidity & $\begin{array}{l}\text { The average relative humidity over the years is } 69 \% \text {, the maximum is } 76 \% \text {, and the minimum is } 65 \% \text {. In the year, the } \\
\text { maximum is from July to August, which is } 85 \% \text {; the minimum is } 13 \% \text { in February }\end{array}$ \\
\hline
\end{tabular}

TABle 2: Design parameters of the retaining wall.

\begin{tabular}{|c|c|}
\hline Design category & Design parameters \\
\hline Load criteria & Auto: over 20; trailer: 120 \\
\hline Safety factor & $\begin{array}{c}\text { 《Specifications for design of highway reinforced earth engineering》 (JTJ015-91) was adopted } \\
\text { With CPE3020 steel-plastic composite belt }\end{array}$ \\
\hline Design parameters of rib & $\begin{array}{c}\text { The breaking force } \geq 7.5 \mathrm{kN} \\
\text { The allowable tensile stress }[\sigma]=110 \mathrm{MPa} \\
\text { The elongation } \leq 2 \%\end{array}$ \\
\hline Panel & $\begin{array}{l}\text { The strength grade of precast concrete is C30 } \\
\text { The horizontal spacing of the joints of the reinforcement is } \mathrm{Sx}=0.5 \mathrm{~m} \\
\text { The vertical spacing of the joints of the reinforcement is } \mathrm{Sy}=0.5 \mathrm{~m} \\
\text { Sandy soil (or gravel soil) with unit weight of } 19.2 \mathrm{kN} / \mathrm{m}^{3}\end{array}$ \\
\hline Filler & $\begin{array}{c}\text { Internal friction angle of } 35^{\circ} \\
\text { Sandy soil with the maximum size of } 10 \mathrm{~cm} \text { is adopted } \\
\text { The friction coefficient between the rib and the filler is } 0.35 \\
\text { The friction coefficient of base is } 0.4\end{array}$ \\
\hline Reinforced foundation & The buried depth of C30 concrete is more than $1.0 \mathrm{~m}$ \\
\hline
\end{tabular}

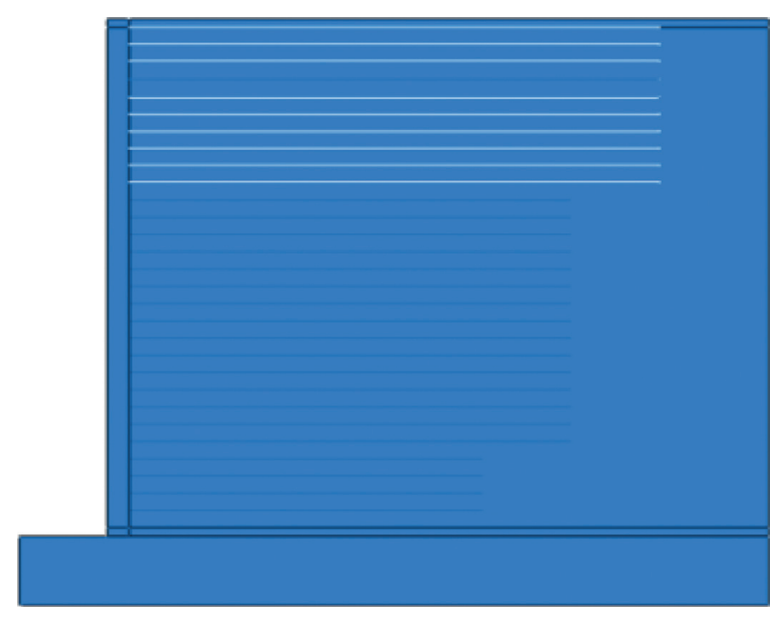

(a)

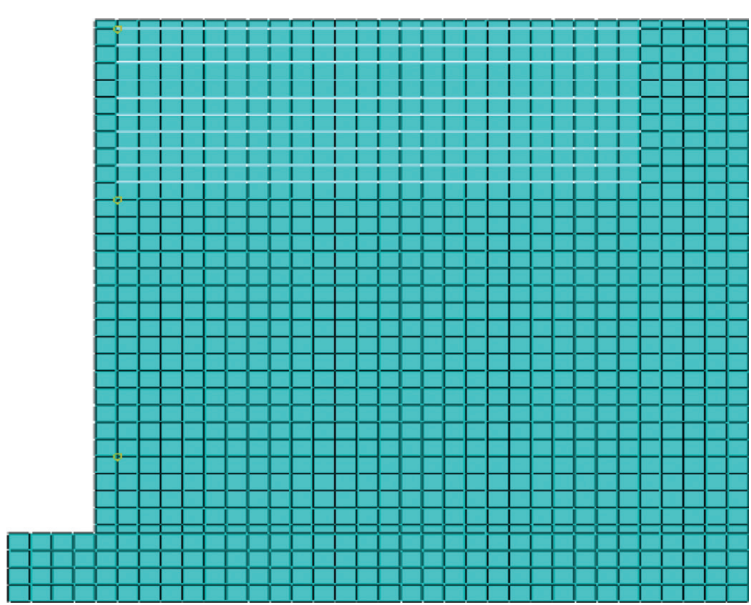

(b)

FIGURE 1: Retaining wall model and finite element mesh.

3.2. Experimental Data Analysis. Figure 2 shows the lateral deformation shape of the wall panel.

The lateral displacement of the reinforced wall panel under a range of working loads is calculated, as shown in Figure 3.

As shown in Figure 4, the lateral displacement of the middle part of the test retaining wall panel calculated using the finite element under different loads is compared with the measured results. It can be seen from the figure that when the working load is small, the calculated lateral displacement of the wall panel is basically consistent with the measured results, which also shows that the finite element numerical analysis method used in this study can reliably estimate the retaining wall panel lateral displacement. 
TABLE 3: Material parameters of the retaining wall.

\begin{tabular}{lcc}
\hline \multirow{3}{*}{ Foundation soil } & Elastic modulus $(\mathrm{MPa})$ & 200 \\
& Poisson's ratio & 0.25 \\
& Weight $\left(\mathrm{kN} / \mathrm{m}^{3}\right)$ & 20 \\
\hline \multirow{3}{*}{ Earth fill } & Elastic modulus $(\mathrm{MPa})$ & 80 \\
& Weight $\left(\mathrm{kN} / \mathrm{m}^{3}\right)$ & 19.2 \\
& Poisson's ratio & 0.3 \\
& Cohesive force $(\mathrm{kPa})$ & 25 \\
\hline \multirow{4}{*}{ Panel } & Dilatancy angle & 11 \\
& Interface reduction factor & 0.67 \\
& Weight $\left(\mathrm{kN} / \mathrm{m}^{3}\right)$ & 23 \\
& Elastic modulus $(\mathrm{MPa})$ & 300 \\
& Poisson's ratio & 0.27 \\
\hline \multirow{3}{*}{ Interface between panel blocks } & Cohesive force $(\mathrm{kPa})$ & 20 \\
& Friction angle & 40 \\
& Interface reduction factor & 0.8 \\
\hline
\end{tabular}

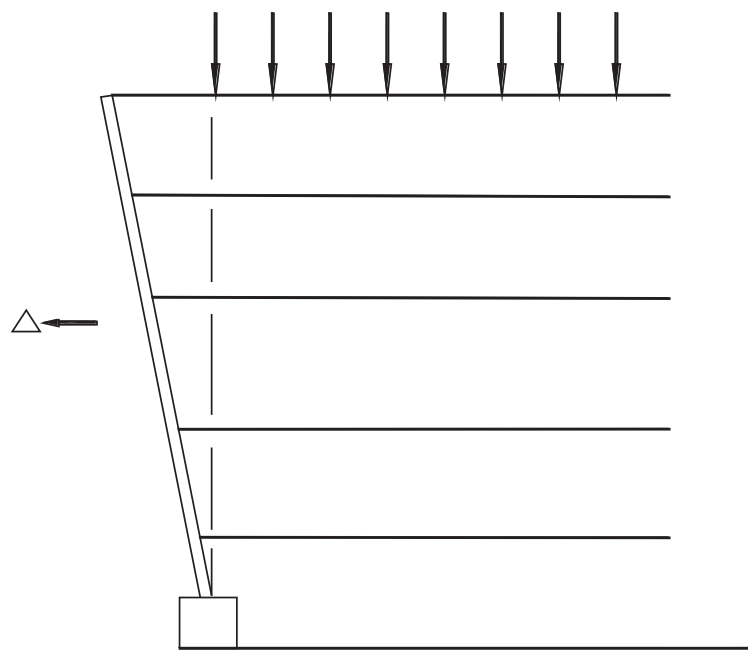

FIGURE 2: Schematic diagram of lateral deformation shape of the wall panel.

As shown in Figure 5, the calculated assumed potential sliding surface is very close to the assumed fracture surface of the limit equilibrium theoretical system, and the distribution trend of the tensile strain of the reinforcement calculated numerically nearly complies with the distribution of the tensile strain of the reinforcement in the assumed active and passive areas of the ascertained data and limit analysis, which displays a better distribution from the panel to the interior of the soil. The last part of the tensile strain value is remarkably small, close to 0 . Such result is achieved because the reinforcement is overly long and of low importance. It is suggested that the stress and strain distribution of the stiffened layer calculated using the finite element is a good verification for the assumption of stress and strain distribution of the stiffened layer in the limit equilibrium design method.

The finite element strength reduction method is adopted here to downregulate the shear strength parameters of the fill from small to large. Subsequently, such method is introduced into the calculation model for calculation, and the plastic belt close to the through is obtained. Under the uniformly distributed load of $5 \mathrm{kPa}$, the reduction factor $\mathrm{F}$ is adopted as 0.5 . Based on the distribution of the tie strip in the soil presented in Figure 6(a), the equivalent plastic zone is illustrated in Figure 6(b). From the

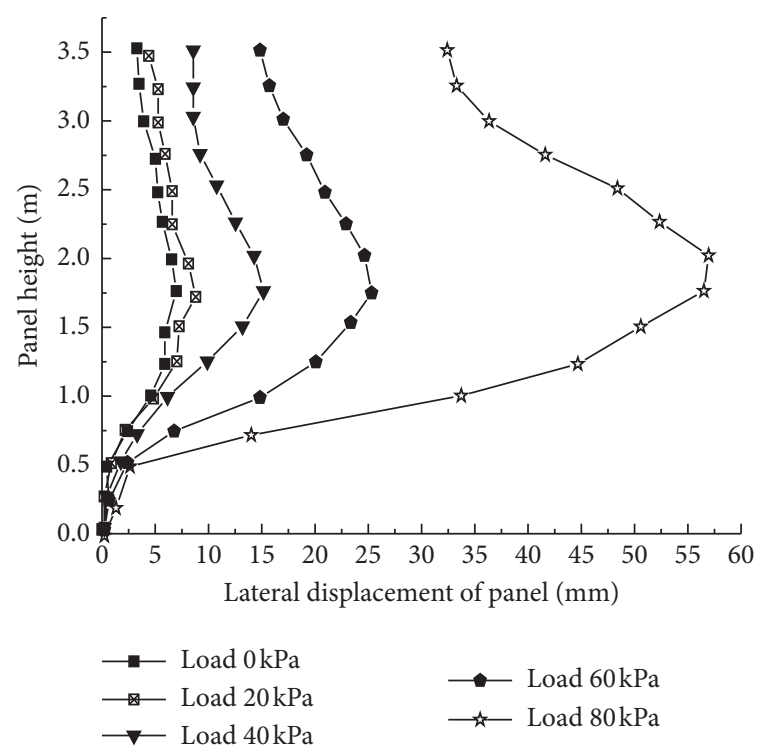

FIgURE 3: Lateral displacement and deformation of wall panel under different loads.

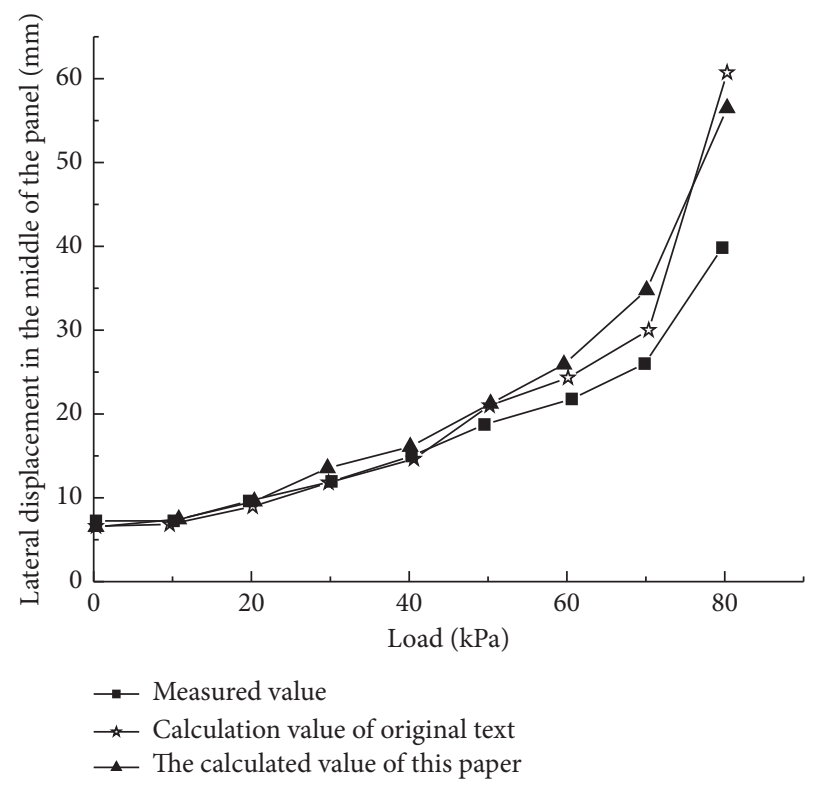

FIgURE 4: Comparison of the calculated and measured lateral displacement of the wall panel.

figure, it is observed that the plastic area first appears near the foot of the wall and subsequently extends to the top of the wall progressively until it runs through. As compared with the most dangerous sliding surface of the retaining wall calculated using the limit equilibrium method, the fracture surface calculated using the finite element has almost the same shape.

\section{Factors Affecting the Lateral Deformation of Wall Panel}

4.1. Comprehensive Impact of Fill. As the backfill of retaining structure, the well-graded granular soil has the advantage of convenient drainage, can improve the durability of the 


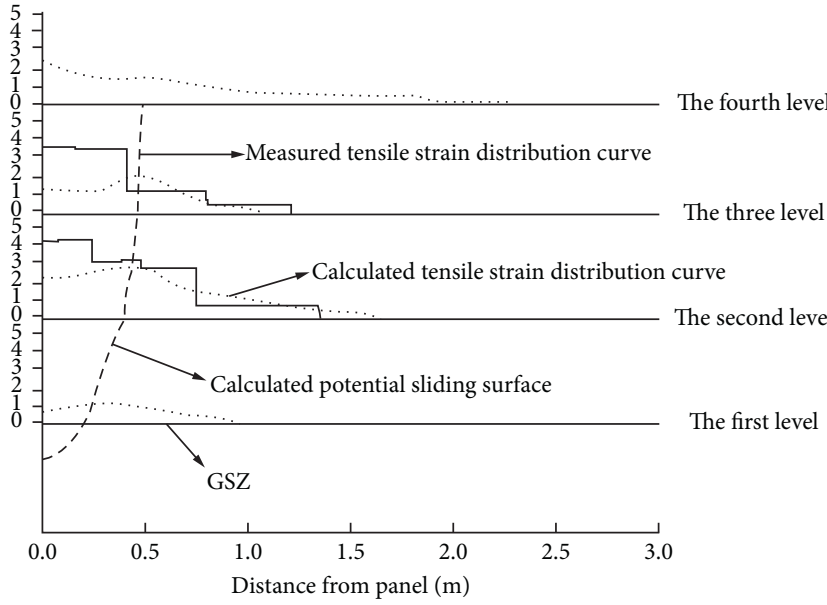

(a)
LE, LE11

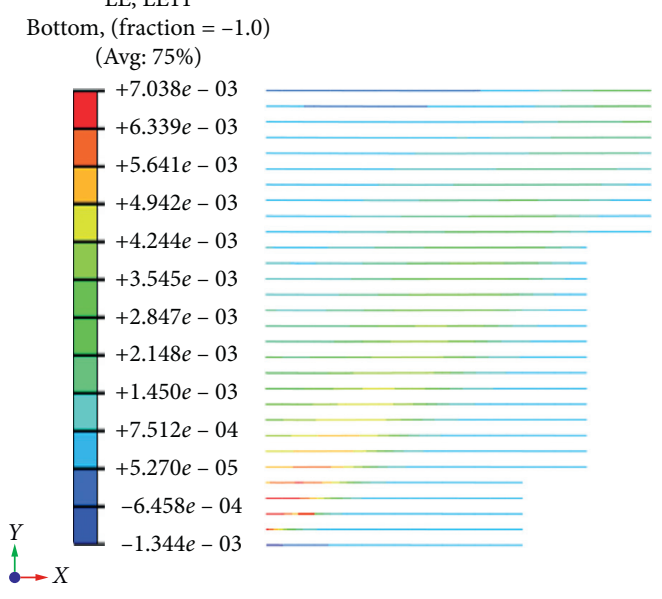

(b)

FIgURE 5: Calculated tensile strain distribution of the reinforced layer (in this study, there are 30 layers of reinforced strip). (a) Assumed fracture surface. (b) The trend of tensile strain distribution of steel bars.

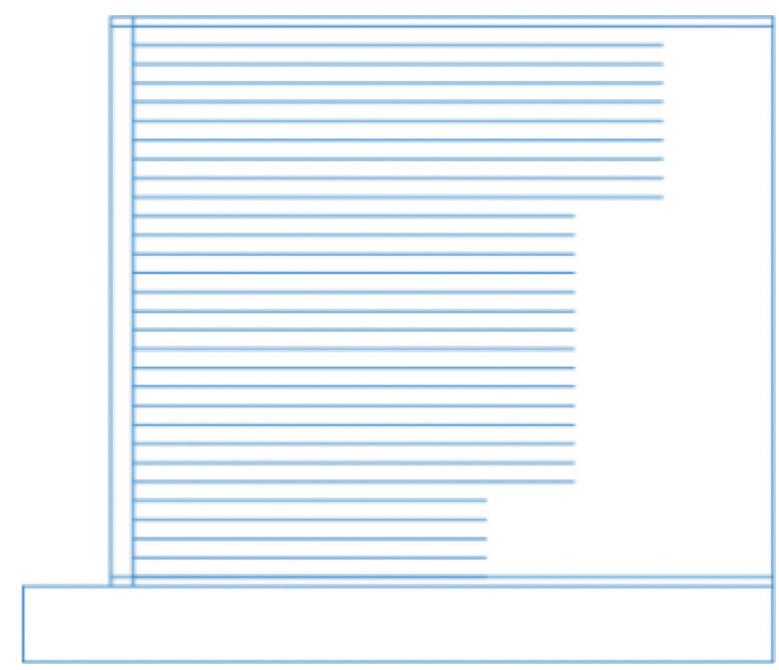

(a)

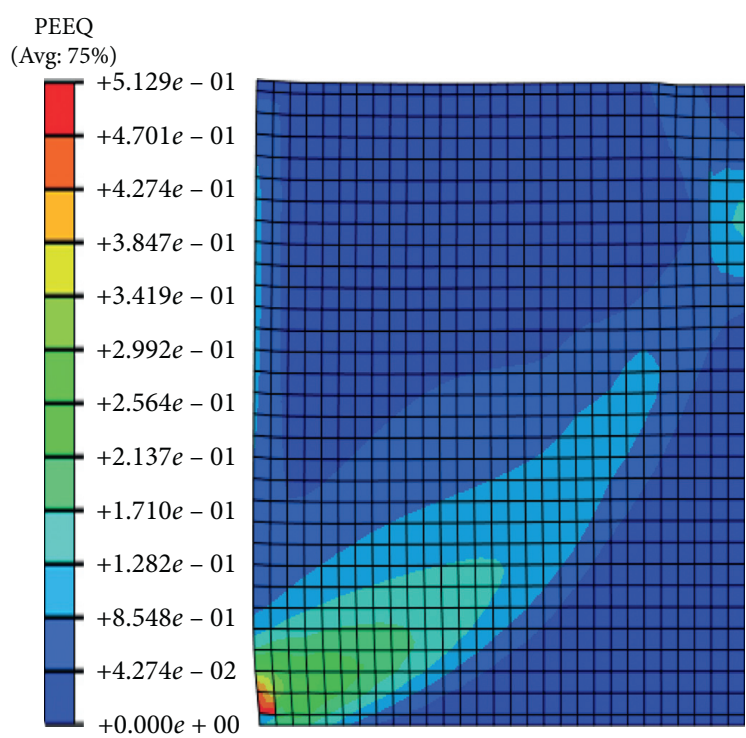

(b)

FIgURE 6: Plastic strain distribution. (a) Distribution of tie bars in soil. (b) Equivalent plastic zone.

geogrid, and reduce the amount of reinforcement. In the meantime, the use of granular soil is also significantly conducive to the process of loading and unloading, filling, and compaction. On the whole, the backfill soil applied for geogrid reinforced retaining wall is granular soil. As listed in Table 4, granular soil is the fill taken for the finite element comparative analysis here. The maximum displacement of the middle part of the calculated panel varies obviously with the properties of the fill, as presented in Figure 7.

Figure 7(a) shows that the selected fill is GW and the lateral displacement of the panel is the minimum. However, the lateral displacement of the slab increases gradually with the change of gradation from gravel to sand. As shown in Figure $7(\mathrm{~b})$, the lateral displacement of the panel decreased from S8 to S5. From Figure 7, it can be seen that the lateral displacement of the panel decreased with the increase of $\varphi$.

\subsection{Effect of Reinforcement Spacing and Reinforcement} Stiffness. Each reinforced retaining wall should have a plan for the arrangement of reinforcement materials. The vertical reinforcement distance is an important part of the plan, which is used to characterize the distance between steel bars. The main function of reinforcement is to restrain the lateral 
TABLE 4: Duncan-Chang constitutive model parameters of representative soil (Mohr-Coulomb).

\begin{tabular}{|c|c|c|c|c|c|c|c|c|c|c|}
\hline \multirow{2}{*}{\multicolumn{2}{|c|}{$\begin{array}{l}\text { Classification } \\
\text { of fill }\end{array}$}} & \multicolumn{3}{|c|}{ Strength characteristic parameters } & \multicolumn{5}{|c|}{ Stiffness characteristic parameters } & \multirow{2}{*}{ Bulk density $\left(\mathrm{kN} \cdot \mathrm{m}^{-1}\right)$} \\
\hline & & $\varnothing_{0}\left({ }^{\circ}\right)$ & $\Delta \varnothing_{0}\left({ }^{\circ}\right)$ & $\mathrm{c}(\mathrm{kPa})$ & $\mathrm{k}$ & $\mathrm{n}$ & $\mathrm{Rf}$ & $\mathrm{kb}$ & $\mathrm{m}$ & \\
\hline GW & $\mathrm{S} 1$ & 42 & 9 & 0 & 600 & 0.4 & 0.7 & 175 & 0.2 & 23.6 \\
\hline GP & S2 & 39 & 7 & 0 & 450 & 0.4 & 0.7 & 125 & 0.2 & 22.8 \\
\hline SW & S3 & 36 & 5 & 0 & 300 & 0.4 & 0.7 & 75 & 0.2 & 22.1 \\
\hline \multirow[t]{2}{*}{ SP } & S4 & 33 & 3 & 0 & 200 & 0.4 & 0.7 & 50 & 0.2 & 21.3 \\
\hline & S5 & 38 & 8 & 0 & 600 & 0.25 & 0.7 & 450 & 0.5 & 21.3 \\
\hline \multirow{3}{*}{ SM } & S6 & 36 & 6 & 0 & 450 & 0.25 & 0.7 & 350 & 0.5 & 20.5 \\
\hline & S7 & 34 & 4 & 0 & 330 & 0.25 & 0.7 & 250 & 0.5 & 19.7 \\
\hline & S8 & 32 & 2 & 0 & 150 & 0.25 & 0.7 & 150 & 0.5 & 18.9 \\
\hline \multicolumn{2}{|c|}{ Explain } & GW: w & raded gra & SW: well- & ed sar & P: poc & rade & vel; S & orly & ed sand; SM: silty sand \\
\hline
\end{tabular}

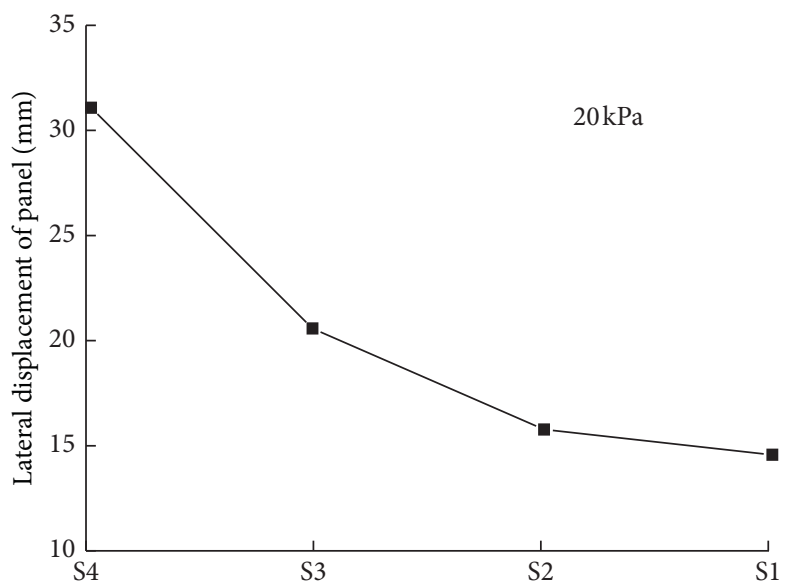

(a)

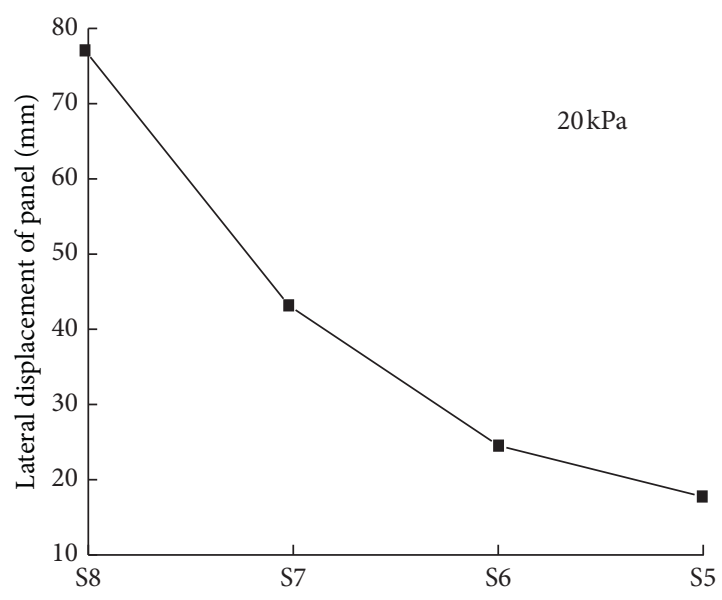

(b)

Figure 7: (a) Variation of lateral displacement of face slab with different backfill (S1-S4). (b) Variation in the lateral displacement of the panel with different backfill (S5-S8).

deformation of the soil body, so that the ultimate strength of the soil body is improved, and the generation and development of the plastic zone are inhibited. On the whole, the smaller the reinforcement spacing, the greater the interface friction will be between the reinforcement and the soil and the more significant the reinforcement effect will be. For the reinforced masonry chamber retaining wall (RMC), four layers of geogrid reinforcement are covered. To explore the effect of the vertical spacing of the reinforced layer on the deformation performance of the reinforced retaining wall, the spacing of the reinforced layers was changed, and then the lateral displacement of the wall panel was calculated when the RMC is reinforced with 30 layers (the spacing of layers is $0.5 \mathrm{~m}$ ), 38 layers (the spacing of layers is $0.4 \mathrm{~m}$ ), and 50 layers (the spacing of layers is $0.3 \mathrm{~m}$ ). According to results, the wall panel with 50 layers of reinforcement displays the smallest overall deformation, and the RMC with 30 layers of reinforcement displays the largest; the more layers reinforcement has, the smaller the overall deformation of the wall panel will be; that is, the lateral deformation of the wall panel is hindered with the decrease in the reinforcement spacing.

Figures 8 and 9 show that as impacted by $40 \mathrm{kPa}$ load, the tensile rigidity of the reinforcement is changed for four types of reinforcement spacing, and the obtained lateral displacement of the retaining wall panel and the maximum tensile strain of the reinforced layer (the third reinforced layer is taken) are compared by the finite element calculation. It is suggested that the maximum lateral displacement of the panel and the maximum tensile strain of the reinforced layer are hindered with the decrease in the reinforcement spacing, as well as with the rise in the reinforcement stiffness.

However, it should also be noted that if the reinforcement spacing is excessively small, it is easy to cause "over reinforced soil," which not only increases the cost and the construction difficulty but also makes no sense in achieving a better reinforcement effect than the moderate reinforcement.

4.3. Effect of Reinforcement Length. The height of RMC is $3.5 \mathrm{~m}$. Under such a height, the design of the reinforced retaining wall with the usual limit equilibrium analysis method suggests that the length of the grid reinforcement layer is about $2 \mathrm{~m}$. According to the finite element analysis results and the actual observation results of RMC, a certain length of reinforcement in the passive area has slight effect. 


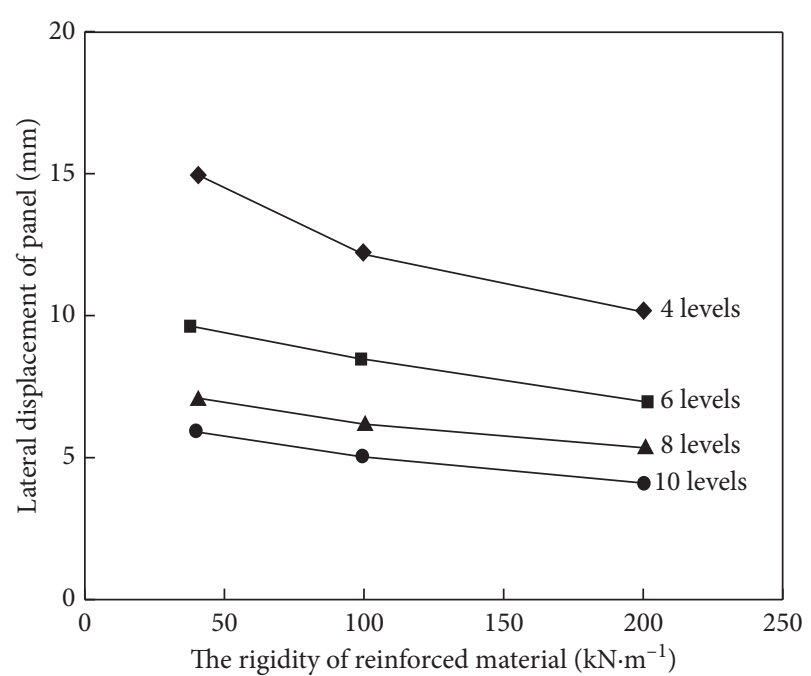

FIGURE 8: Change of lateral displacement of panel with reinforcement stiffness.

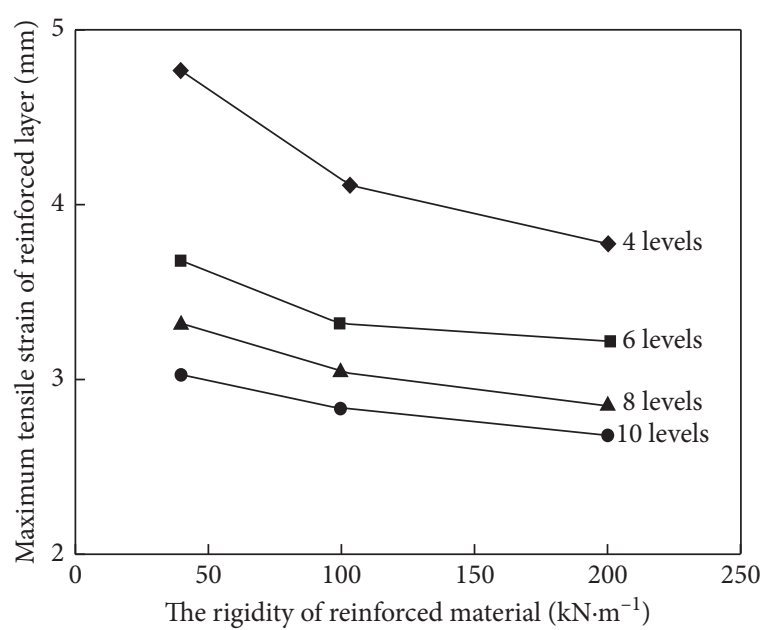

Figure 9: Dependence of maximum tensile strain of the reinforced layer on reinforcement stiffness.

Accordingly, the reinforced length of RMC is varied, and the finite element comparative calculation is conducted to delve into the effect of the reinforced length on the working performance of the retaining wall. Furthermore, the length of reinforcement is $1.8 \mathrm{~m}, 2.4 \mathrm{~m}$, and $3.6 \mathrm{~m}$, and the number of layers remains unchanged.

Under the identical $40 \mathrm{kPa}$ overburden load, the lateral displacement of the wall panel with the mentioned three reinforcement lengths is calculated using the finite element, and the results are compared with those of the actual RMC at the reinforcement length of $3 \mathrm{~m}$. According to the results, there is no obvious variation rule of the lateral deformation of the wall panel at a range of reinforcement lengths, and the calculated maximum lateral displacement of the wall panel is also similar. Table 5 draws a comparison of the maximum lateral displacement of the wall panel at the four reinforcement lengths. The maximum lateral displacement decreased with the increase of the reinforcement length within a certain range. As suggested by the corresponding data of the reinforcement length and the maximum lateral displacement of the wall panel in the table, the lateral deformation of the retaining wall panel will not definitely become smaller with the lengthening of the reinforcement length. It is therefore concluded that the reinforced material only requires a certain length to resist the sliding failure of the soil. In the case of a certain wall height, there is a certain limit value for the reinforced length, namely, when the reinforced length reaches over a certain value, there will be reinforcement surplus, and the surplus reinforcement is not involved, so it is not always feasible to improve the lateral deformation of the wall panel by upregulating the length of the reinforcement.

4.4. Effect of Panel Stiffness. To analyze the effect of the panel stiffness on the performance of the reinforced retaining wall, the finite element calculation is carried out by changing the elastic modulus of the beam element material to discuss the influence of the change of the panel stiffness on its deformation. The section area $\mathrm{A}$ and section inertia moment I of the panel remain unchanged, and the elastic modulus value is changed for calculation, which is shown in Table 6. The results of numerical calculation show that the lateral deformation of the wall panel as impacted by $20 \mathrm{kPa}$ uniform load is corresponding to different panel types.

Figure 10 shows the comparison of the lateral displacement at a point in the middle of the panel corresponding to the mentioned four panel types. It can be concluded that the larger the elastic modulus of the panel, the smaller the lateral deformation will be. When the section of the panel is constant, it can be considered that the lateral deformation decreases with the rise in the panel stiffness.

\section{Analysis of Calculation Examples of Different Wall Heights}

Taking the vertical reinforced retaining wall as the research object, the grid spacing is set as $0.5 \mathrm{~m}$, the reinforced length is $4.5 \mathrm{~m}, \gamma=18 \mathrm{kN} / \mathrm{m}^{3}$, and the internal friction angle of the soil is 30 degrees.

According to the parameter characteristics of engineering examples, the rigidity of reinforcement material reaches $50 \mathrm{kN} / \mathrm{m}$, the elasticity modulus of concrete with panel rigidity is $E=140 \mathrm{MPa}$, and the area and inertia moment of section per unit length are $A=25 \mathrm{~cm}^{2} / \mathrm{cm}$, $\mathrm{I}=40 \mathrm{~cm}^{4} / \mathrm{cm}$. The situation should be considered when the construction is completed.

Figure 11 shows the horizontal displacement diagram of retaining walls with a range of wall heights at the panel. It is suggested that the upper and lower deformations of retaining walls are relatively small, and the maximum displacement occurs between the height of (1/3-1/2) $\mathrm{H}$ from the bottom of the wall and obviously increases with the rise in height, showing a similar change trend.

By analyzing the maximum tensile force of each layer of the retaining wall with a range of wall heights, the distribution of the maximum tensile force of the reinforcement is 
TABLE 5: Comparison of maximum lateral displacement of the wall panel.

\begin{tabular}{lcccc}
\hline Reinforcement length $(\mathrm{m})$ & 1.8 & 2.4 & 3.0 & 3.6 \\
\hline Maximum lateral displacement $(\mathrm{mm})$ & 19.3 & 17.2 & 16.6 & 16.4 \\
\hline
\end{tabular}

TABle 6: Change in value of elastic modulus $E$ of the wall panel.

\begin{tabular}{lcccc}
\hline Modulus of elasticity category & 1 & 2 (RMC) & 3 & 4 \\
\hline E $(\mathrm{MPa})$ & 1400 & 140 & 14 & 1.4 \\
\hline
\end{tabular}

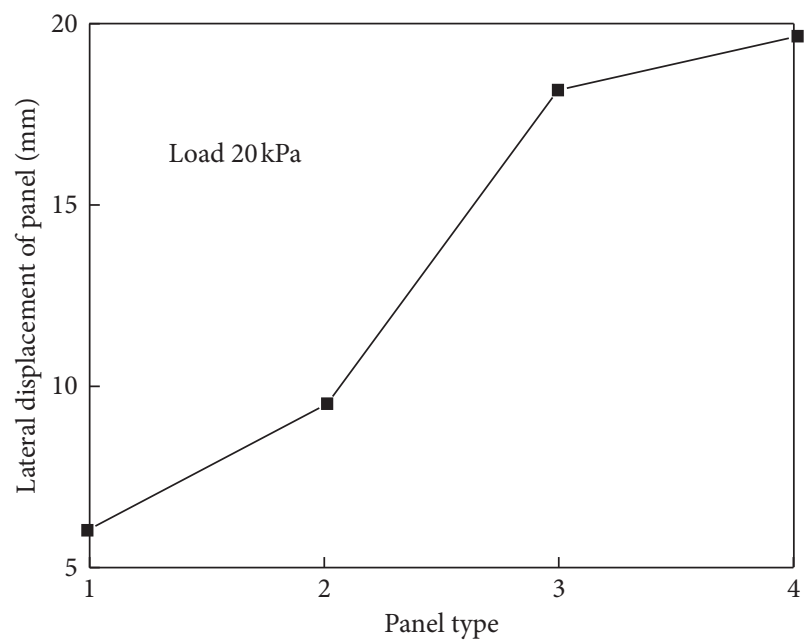

FIgURE 10: Dependence of the lateral displacement of the panel on its stiffness.

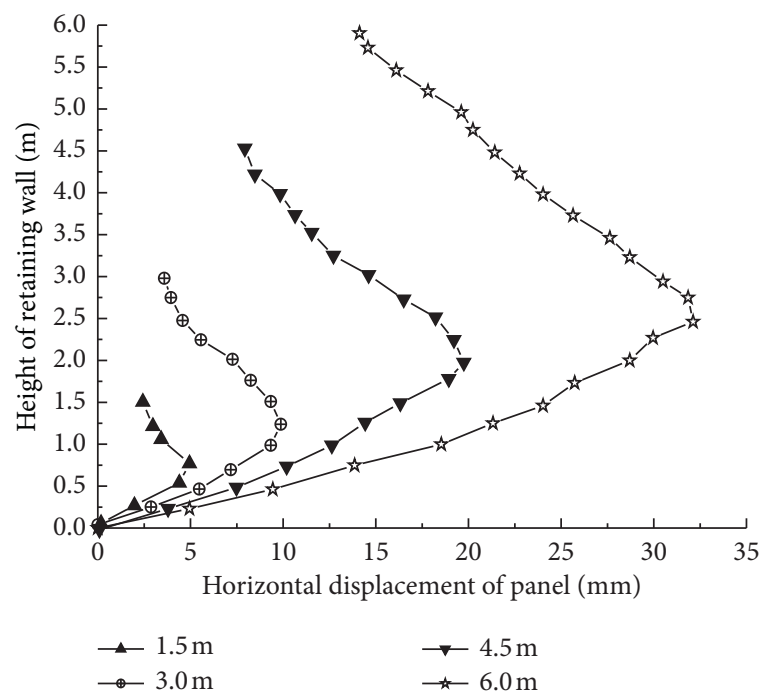

FIgURE 11: Horizontal displacement of different retaining walls.

associated with the wall height, showing a similar trend of change. As shown in Figure 12, the upper and lower deformations of the retaining wall are relatively small, and the maximum value appears between the height of $(1 / 3-1 / 2) \mathrm{H}$ from the wall bottom.

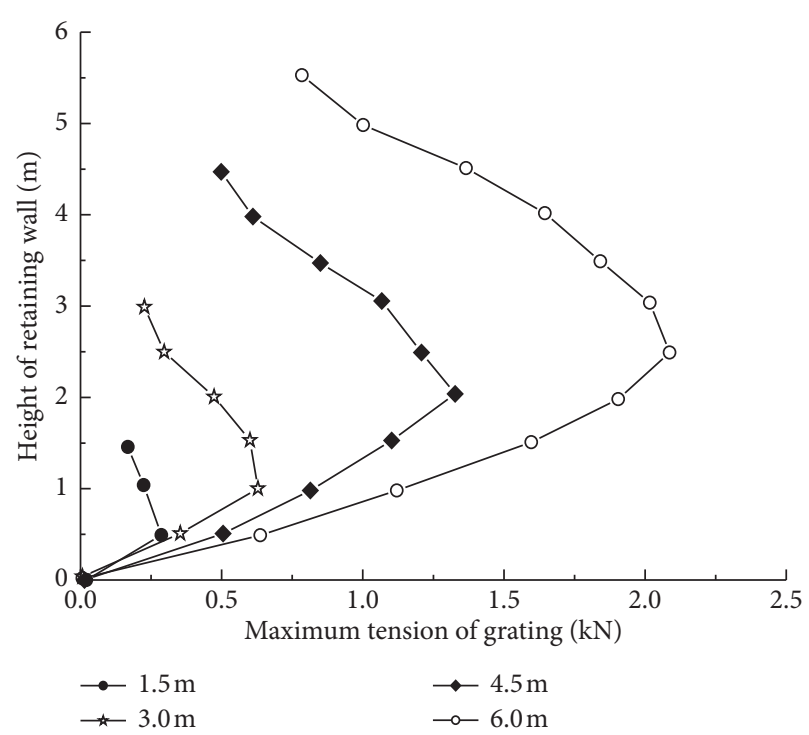

FIGURE 12: Variation of the maximum tensile force of the grille along the wall height.

\section{Conclusions}

The numerical analysis of RMC is conducted using the finite element method, and the mechanical characteristics of the reinforced retaining wall were investigated. Based on the test results, the following conclusions are made:

(1) The maximum deformation value is greatly affected by the type of filling behind the wall. The lateral displacement of the slab increases gradually with the change of gradation from gravel to sand and decreased with the increase of $\varphi$. Therefore, in the actual construction, the soil with a small friction angle and good gradation should be selected as far as possible.

(2) In terms of stiffener spacing and stiffener stiffness, the more layers reinforcement has, the smaller the overall deformation of the wall panel will be, and the maximum lateral displacement of the panel and the maximum tensile strain of the reinforced layer are hindered by the decrease in the reinforcement spacing, as well as with the rise in the reinforcement stiffness. However, if the reinforcement spacing is excessively small, it is easy to cause "over reinforced soil", which not only increases the cost and the construction difficulty but also makes no sense in achieving a better reinforcement effect than the moderate reinforcement.

(3) The reinforced material only requires a certain length to resist the sliding failure of the soil. In the case of a certain wall height, there is a certain limit value for the reinforced length, namely, when the reinforced length reaches over a certain value, there will be reinforcement surplus, and the surplus reinforcement is not involved, so it is not always feasible to improve the lateral deformation of the wall panel by upregulating the length of the reinforcement. 
(4) By analyzing the influence of retaining wall stiffness on retaining wall deformation, we find that the larger the elastic modulus of the panel, the smaller the lateral deformation will be. When the section of the panel is constant, it can be considered that the lateral deformation decreases with the rise in the panel stiffness.

(5) By comparing and analyzing the influence of different wall heights on the deformation of the retaining wall, it is found that the maximum displacement of the panel and the maximum tensile force of the grid appear between the height of (1/3-1/ 2) $\mathrm{H}$ from the wall bottom. Thus, it is necessary to enhance the strength of this distance and lay more dense reinforcement to prevent the retaining wall from cracking and failing at this position.

\section{Data Availability}

The data used to support the findings of this study are included within the article.

\section{Conflicts of Interest}

The authors declare that there are no conflicts of interest regarding the publication of this paper.

\section{Acknowledgments}

This study was supported by the Shandong Provincial Natural Science Foundation (ZR2020QE274), Key Research and Development Program of Shandong Province (Soft Science Project) (2020RKB01602), and Science and Technology Plan of Shandong Transportation Department (2019B63, 2020B93).

\section{References}

[1] A. M. Krishna and G. M. Latha, "Modeling the dynamic response of wrap-faced reinforced soil retaining walls," International Journal of Geomechanics, vol. 12, no. 4, pp. 439450, 2011.

[2] Y. Zhu, D. Bi, and Y. Zhou, "Numerical simulation and analysis of stability of vertical reinforced retaining wall," Journal of Lanzhou University of Technology, vol. 37, no. 2, pp. 106-110, 2011.

[3] H. Liu and M.-S. Won, "Stress dilatancy and reinforcement load of vertical-reinforced soil composite: analytical method," Journal of Engineering Mechanics, vol. 140, no. 3, pp. 630-639, 2014.

[4] K. Maehara, A. Hamanaka, T. Sasaoka, H. Shimada, S. Sakuma, and W. Y. Wang, "Study on control of wall deflection in earth stepped-twin retaining wall using anchor method by means of numerical simulation," Advances in Civil Engineering, vol. 2020, Article ID 2710954, 8 pages, 2020.

[5] X. Zhou, "A study on strength and deformation of reinforced earth retaining wall at roadbed shoulder," Journal of the China Railway Society, vol. 1, pp. 94-100, 1994.

[6] X. Zhou, "Analysis of strength and deformation of reinforced earth retaining wall," Journal of Beijing Jiaotong University, vol. 4, pp. 96-100, 1987.
[7] G. Yang, Y. Cai, and Q. Su, "Testing study on deformation and stress of reinforced earth retaining wall for high embankment," Chinese Journal of Rock Mechanics and Engineering, vol. 2, pp. 321-326, 2003.

[8] M. Ehrlich, S. H. Mirmoradi, and R. P. Saramago, "Evaluation of the effect of compaction on the behavior of geosyntheticreinforced soil walls," Geotextiles and Geomembranes, vol. 34, pp. 108-115, 2012.

[9] L. Li, A. Shi, and H. Xiao, "Model test and mechanical properties study of reinforced earth retaining wall," Rock and Soil Mechanics, vol. 39, no. 12, pp. 4360-4368, 2018.

[10] C. Xiao, J. Wang, and X. Zhuo, "Performance of geogridreinforced soil retaining walls subjected to static and cyclic footing loadings," Chinese Journal of Rock Mechanics and Engineering, vol. 36, no. 6, pp. 1542-1550, 2017.

[11] A. Abdelouhab, D. Dias, and N. Freitag, "Numerical analysis of the behaviour of mechanically stabilized earth walls reinforced with different types of strips," Geotextiles and Geomembranes, vol. 29, no. 2, pp. 116-129, 2011.

[12] H. I. Ling, S. Yang, D. Leshchinsky, H. Liu, and C. Burke, "Finite-element simulations of full-scale modular-block reinforced soil retaining walls under earthquake loading," Journal of Engineering Mechanics, vol. 136, no. 5, pp. 653-661, 2010.

[13] G. Yang, "Experimental study on working performance of reinforced earth retaining wall under equivalent static load," Journal of the China Railway Society, vol. 2016, no. 3, pp. 97-99, 2016.

[14] X. Li, Y. Wu, and S. He, "Seismic stability analysis of gravity retaining walls," Soil Dynamics and Earthquake Engineering, vol. 30, no. 10, pp. 875-878, 2010.

[15] K. Ahn, H. Kang, and R. Cerný, "Behavior of reinforced retaining walls with different reinforcement spacing during vehicle collisions," Advances in Materials Science and Engineering, vol. 2015, Article ID 920628, 9 pages, 2015.

[16] X. Jiang, T. Chen, and Y. Wu, "Numerical simulation on stability development of geogrid reinforced widening embankment with rigid retaining wall," Journal of Southwest Jiaotong University, vol. 53, no. 5, pp. 1000-1008, 2018.

[17] H. Liu, "Long-term lateral displacement of geosyntheticreinforced soil segmental retaining walls," Geotextiles and Geomembranes, vol. 32, pp. 18-27, 2012.

[18] H. Lu and J. Wang, "Application of numerical simulation analysis in reinforced retaining wall engineering," Coal Engineering, vol. 2011, no. 10, pp. 43-45, 2011.

[19] S. Ambauen, B. Leshchinsky, Y. Xie et al., "Service-state behavior of reinforced soil walls supporting spread footings: a parametric study using finite-element analysis," Geosynthetics International, vol. 23, no. 3, pp. 156-170, 2015.

[20] K. Z. Z. Lee, N. Y. Chang, and H. Y. Ko, "Numerical simulation of geosynthetic-reinforced soil walls under seismic shaking," Geotextiles and Geomembranes, vol. 28, no. 4, pp. 317-334, 2010 .

[21] Q. Chang, Y. Shu, and S. Huang, "Effect of bar spacing on performance of reinforced soil retaining walls," Journal of Hohai University (Natural Sciences), vol. 2007, no. 5, pp. 557-562, 2007.

[22] He Wang, G. Yang, Z. Wang, and W. Liu, "Static structural behavior of geogrid reinforced soil retaining walls with a deformation buffer zone," Geotextiles and Geomembranes, vol. 48 , no. 3, 2020.

[23] W. Hu, K. Liu, X. Zhu, X. Tong, X. Zhou, and A. S. Larbi, "Active earth pressure against rigid retaining walls for finite soils in sloping condition considering shear stress and soil 
arching effect," Advances in Civil Engineering, vol. 2020, Article ID 6791301, 11 pages, 2020.

[24] W. D. Finn, "Application of limit plasticity in mechanics," Journal of the Soil Mechanics and Foundations Division, ASCE, vol. 93, no. 5, pp. 101-102, 1967.

[25] W. F. Chen and C. R. Scawthorn, "Limit analysis and limit equilibrium solutions in soil mechanics," Soils and Foundations, vol. 10, no. 3, pp. 13-49, 1970.

[26] X. Jia, J. Xu, Y. Sun, and A. Cordero, "Deformation analysis of reinforced retaining wall using separate finite element," Discrete Dynamics in Nature and Society, vol. 2018, Article ID 6946492, 9 pages, 2018.

[27] R. L. Handy, "The arch in soil arching," Journal of Geotechnical Engineering, vol. 111, no. 3, pp. 302-318, 1985.

[28] P. A. Vermeer, A. Punlor, and N. Ruse, "Arching effects behind a soldier wall," Computers and Geotechnics, vol. 28, no. 6-7, pp. 379-396, 2001.

[29] J. M. Duncan and R. L. Mokwa, "Passive earth pressures: theories and tests," Journal of Geotechnical and Geoenvironmental Engineering, vol. 127, no. 3, pp. 248-257, 2001. 